\title{
Prevalence of Asthenopia in Visual Display Terminal Operators at Federal International Finance Group Bali
}

\author{
I Putu Oka Primantara ${ }^{1}$, Sagung Putri Permana Lestari Murdhana Putere ${ }^{\mathbf{1}^{*}}$ \\ ${ }^{1}$ Faculty of Medicine and Health Sciences, Universitas Warmadewa, Denpasar, Bali \\ *putrip184@gmail.com
}

\begin{abstract}
Asthenopia is a group of symptoms or complaints in the eye that generally appear when reading or work that requires precision. One of the occupations that are at risk for impaired asthenopia are employees who use computers at the Federal International Finance (FIF) Group Bali. This study aims to determine the percentage of asthenopia disorders based on asthenopia symptoms experienced. This study was descriptive study with cross-sectional approach among the FIF employes who work on the computer. The variables included asthenopia disorders, age, gender, VDT settings, screen filters, duration of work, and rest duration, room and angle lighting formed between the top of the monitor and the midpoint of the screen. The most common complaint was headache as many as 38 respondents $(79.16 \%)$. The incidence of asthenopia in the age group of 21-40 years was a headache of 28 respondents $(58.4 \%)$, and at the age of 41-60 years was a headache of 10 respondents (20.9\%). The highest prevalence of asthenopia in room lighting settings <200 lux was headache as much as 19 respondents (39.6\%), while in room lighting 200 lux-500 lux was blurred vision with as many as 10 respondents $(23 \%)$.
\end{abstract}

Keyword : Prevalence, Terminal Operators, Finance Group Bali.

\section{Introduction}

Computer utilization in the era of information technology has provided a lot of success in work and saves a lot of time, but this utilization causes an increase in eye complaints classified as Computer Visions Syndrome (CVS). This state of tired eyes is called asthenopia [1].

Asthenopia is a group of symptoms or complaints in the eye that generally appear when reading or work that requires precision. Asthenopia has non-specific symptoms such as a feeling of being tired of the eyes, burning sensation, irritation, pain, itching, and headache. Specific symptoms in humans are photophobia, blurred vision, double vision, watery eyes, dry eyes, and the presence of foreign body sensations. Common causes of asthenopia are refractive disorders that is not treated and environmental factors such as contrasting light [2]. Untreated asthenopia can result in cataracts or other visual impairment diseases so that it can cause blindness. This is caused by exposure to radiation from a computer that is too long so that it can cause turbidity in the lens [3].

Research conducted in India stated that as many as $46.3 \%$ of computer users experienced fatigue in the eye and in Australia as much as 63.4\% [4]. The incidence in America as many as $77.4 \%$ of the population using computers reported experiencing asthenopia and $90 \%$ were in the age range of 5 to 17 years. 2 Research conducted in Indonesia on 72 call center employees in South Jakarta stated that $68.1 \%$ experienced eye fatigue, headaches in $54.2 \%$, and dry eyes in $43.1 \%$ [5]. 
Until now no research has been found on Visual Display Terminal (VDT) in Bali, Indonesia so researchers were interested in conducting research on a percentage of asthenopia incidence in the Federal International Finance (FIF) Group Bali. The staff in FIF using computer at least 8 hours everyday.

\section{Method}

\subsection{Sample collection}

This research was conducted on VDT operators at FIF Group Bali during December 2017. This study is a descriptive study with a cross-sectional approach using primary data obtained from interviews and questionnaires. The variables studied in this study included age, sex, duration of work, duration of rest, distance from the monitor to operators' eyes, angle formed, screen filter and asthenopia disorders. Samples were obtained by total sampling as many as 48 people who had met the inclusion criteria such as working at least one year, working for more than 6 hours and willing to become respondents. Data will be analyzed descriptively using SPSS v.21. Retrieving data was done by interviews and questionnaires.

\subsection{Ethical Consideration}

The study, the collection of clinical and epidemiological data submitted for ethical approval to the Research Ethic Committee of Universitas Udayana, Denpasar, Bali, Indonesia. Enrolment of the study participants is conditional on appropriate consent..

\section{Results And Discussion}

The most common complaints are headaches in as many as 38 respondents $(79.16 \%)$, followed by tired eyes as many as 36 respondents $(75 \%)$, short-distance blurred vision of 34 respondents $(70.8 \%)$, long distance blurred vision of 34 respondents $(70.8 \%)$, sensitive to light as many as 28 respondents $(58.4 \%)$, eyes redness as many as 25 respondents $(52.1 \%)$, neck strain as many as 19 respondents (39.7\%), eye itching as much 18 respondents $(37.3 \%)$, dry eyes or watery eyes as many as 16 respondents $(33.3 \%)$, and double vision as many as 12 respondents $(25 \%)$.

Table 1 Characteristics of respondents based on age, sex, duration of work, duration of rest, distance from the monitor to the eyes, angle formed, computer screen filter, and room lighting.

\begin{tabular}{llcc}
\hline \multicolumn{1}{c}{ Variable } & \multicolumn{1}{c}{ Category } & N & Percentage (\%) \\
\hline Age (Years) & $21-40$ & 37 & $77.1 \%$ \\
& $41-60$ & 11 & $22.9 \%$ \\
Sex & Male & 28 & $58.3 \%$ \\
\multirow{2}{*}{ Work Duration (hours) } & Female & 20 & $41.7 \%$ \\
\multirow{2}{*}{ Rest Duration (hours) } & $\leq 10$ hours & 7 & $14.58 \%$ \\
\multirow{2}{*}{ Distance between eyes and monitor(cm) } & $>10$ hours & 41 & $85.41 \%$ \\
& $<2$ hours & 43 & $89.6 \%$ \\
& Ergonomic & 5 & $10.4 \%$ \\
& Non-ergonomic & 17 & $35.4 \%$ \\
& & 31 & $64.6 \%$ \\
\hline
\end{tabular}




\begin{tabular}{llcc}
\hline Angle formed & $10-20^{\circ}$ (ergonomic) & 17 & $72.9 \%$ \\
& $<10^{\circ} \&>20^{\circ}$ (non- & & \\
& ergonomic) & 31 & $27.1 \%$ \\
Computer's screen filter & Yes & 9 & $18.8 \%$ \\
& No & 39 & $81.2 \%$ \\
Room lighting & $<200$ Lux & 26 & $54.2 \%$ \\
& $200-500$ Lux & 11 & $22.9 \%$ \\
& $>500$ Lux & 11 & $22.9 \%$ \\
\hline
\end{tabular}

Table 2. Distribution of asthenopia complaints

\begin{tabular}{lcc}
\hline \multicolumn{1}{c}{ Asthenopia Complaints } & N & Percentage (\%) \\
\hline Headache & 38 & $79.16 \%$ \\
Tired eyes & 36 & $75 \%$ \\
Red eyes & 25 & $52.1 \%$ \\
Short-distance blurred vision & 34 & $70.8 \%$ \\
Light-sensitivity & 28 & $58.4 \%$ \\
Long-distance blurred vision & 34 & $70.8 \%$ \\
Dry eyes or watery eyes & 16 & $33.3 \%$ \\
Itchy eyes & 18 & $37.3 \%$ \\
Double vision & 12 & $25 \%$ \\
Strained on the neck and shoulders & 19 & $39.7 \%$ \\
\hline
\end{tabular}

Based on the results of cross-tabulation of asthenopia complaints against age, the most age group at the age of 21-40 is headache as many as 28 respondents $(58.4 \%)$, in the age group 41 60 years the headache was ranked as high as 10 respondents $(20,9 \%)$. The category with few complaints, does not interfere with the most work is headache as many as 26 respondents $(54.2 \%)$ in the age group 20-40 years and 9 respondents $(18.8 \%)$ in the age group $41-60$. The complaints that interferes with work for $<24$ hours, mostly found in tired eyes with a frequency of 12 respondents $(25 \%)$ in the age group $21-40$ and 4 respondents $(8.3 \%)$ in the age group 41-60 years. The complaints category is very disturbing, loss $>24$ hours is mostly found in blurred long distance vision of 6 respondents $(12.5 \%)$.

Based on the results of cross-tabulation of asthenopia complaints against gender, the sex that experienced the most asthenopia disorders in men was headache with a frequency of 21 respondents $(43.8 \%)$, whereas in women was a blurred vision at close distance with a frequency of 17 respondents $(35.5 \%)$. The category with few complaints, does not interfere with the most work on male respondents is headache as many as 20 respondents (41.7\%), while in women the most complaints are headaches with a frequency of 15 respondents $(31.2 \%)$. Complaints category disrupted work, improving in $<24$ hours most were found in tired eyes with a frequency of 10 respondents $(20.8 \%)$ in male, while most female was found in tired eyes with a frequency of 6 respondents $(12.5 \%)$. The category of complaints that severely disrupts work in > 24 hours most often in long distance blurred views with a frequency of 3 respondents $(6.2 \%)$ in male sex and long distance blurred views on female with a frequency of 3 respondents $(6.2 \%)$.

Based on the results of cross-tabulation of asthenopia complaints on room lighting, in room lighting settings <200 lux the most complaints were headaches as much as $19(39.6 \%)$ respondents, while in room lighting 200 lux-500 lux blurred vision at close range with a frequency of 10 respondents $(23 \%)$ and in room lighting >500 lux were tired eyes with a frequency of 11 respondents $(22.9 \%)$. Minimal complaint category, not disturbing work on room lighting respondents $<200$ lux most are headaches as many as 17 respondents $(35.4 \%)$, 
in lighting rooms 200-500 lux are headaches with a frequency of 9 respondents (18.8\%) and in room lighting $>500$ lux is headache with a frequency of 9 respondents $(18.8 \%)$. In room lighting <200 lux the work-disturbing category, lost $<24$ hours is found in tired eyes with a frequency of 6 respondents $(12.5 \%)$, while lighting in rooms 200-500 lux is tired eyes with a frequency of 6 respondents $(12,5 \%)$ and in room lighting $>500$ lux are tired eyes with frequency of $8(16.7 \%)$ respondents. Highly-disturbing work category, diminishing in $\geq 24$ hours in room lighting <200 lux is a close range blurred view of 3 respondents $(6.2 \%)$, then in the lighting room 200-500 lux the most in long distance blurred view with a frequency of 2 respondents $(4.2 \%)$. This research was conducted on VDT employees at FIF Group Bali, where men had a greater frequency of 28 (58.3\%) respondents and 20 women (41.7\%) respondents. This is in line with the research conducted by Mansoori and friends in Karachi, Pakistan on 150 people who use computers at least 2 hours a day. In this study more respondents were men with a percentage of men as many as $117(78 \%)$ respondents and women $33(22 \%)$ respondents [6]. This is different from the research conducted by Suharyanto on call center employees in Jakarta, where in the study all samples totaling 72 respondents all involved female respondents. That is because the study wanted to know the prevalence of asthenopia in women only, because according to the literature women tend to experience more complaints of asthenopia. The research that we did used the sample characteristics of men and women, because in this study we wanted to find out the overall prevalence of complaints of asthenopia in the company FIF Group Bali. In this study it is not possible to conduct research on only female samples, because the number of women who meet the criteria is not in accordance with the number of sample sizes needed.

In this study most respondents work using computers more than 10 hours a day with a frequency of $41(85.41 \%)$ and only $7(14.58 \%)$ respondents work less than or equal to 10 hours a day. Most of the respondents' rest periods are less than 2 hours a day with $43(89.6 \%)$ respondents. This has the same duration of work and rest characteristics in a study conducted by the Department of Ophthalmology, Faculty of Medicine, in Malaysia for students who use computers with a minimum duration of more than 2 hours per day, finding data that most respondents work more than 10 hours per day and with breaks of less than 2 hours [7]. The ideal work duration is a maximum of 10 hours a day or 42 hours a week so that an employee can work optimally [8]. While the duration of a good rest is at least 2 hours a day or an employee gets a morning break of 15 minutes, lunch breaks for 1 hour 30 minutes and an afternoon break for 15 minutes, so that an employee gets a total of 2 hours of rest a day [9].

The measurement results with a meter to the distance from the monitor to the eye, most of the distance from the monitor to the eye are in the non-ergonomic category with a frequency of $31(64.6 \%)$ and the ergonomics category as many as $17(35.4 \%)$. The angle formed by the vision to the monitor which is categorized as ergonomics is $10^{\circ}-20^{\circ}$ with a frequency of 37 $(72.9 \%)$, while those in the non-ergonomic category are within $<10$ and $>20^{\circ}$ with each frequency numbering $11(27.1 \%)$. The number of screen filters used on computers with a frequency of $9(45.8 \%)$, while the number that does not use screen filters on computers is 39 $(81.2 \%)$. Ergonomic room lighting category is 200-500 lux with a frequency of $11(22.9 \%)$, while non-ergonomics with room lighting $<200$ lux and $>500$ lux each have a frequency of 26 $(54.9 \%)$ and $11(22,9 \%)$. This is in line with the research conducted by Riski et al who obtained data that the characteristics of the distance from the monitor to the eye, the angle formed by the view to the monitor screen, the use of screen filters and room lighting were obtained non-ergonomic data [10].

The most experienced complaints of asthenopia are headaches in $38(79.16 \%)$ respondents, followed by tired eyes in $36(75 \%)$ respondents, close-distance blurred vision in 
$34(70.8 \%)$ respondents, long-distance blurred vision in $34(70,8 \%)$ respondents, light sensitivity in $28(58.4 \%)$ respondents, red eyes in $25(52.1 \%)$ respondents, neck strains in 19 $(39.7 \%)$ respondents, itching in the eyes in $18(37.3 \%)$ respondents, dry eyes or watery eyes in $16(33.3 \%)$ respondents, and double vision as many as $12(25 \%)$ respondents. This is in accordance with research conducted by the Department of Ophthalmology, Faculty of Medicine, in Malaysia which found that the highest frequency of complaints is headache in $157(19.7 \%)$ respondents, $130(16.4 \%)$ tired eyes, and the rest followed by other complaints.7

In this study also presented complaints of asthenopia against age, asthenopia complaints on sex, and asthenopia complaints on room lighting settings. Headache is the most common complaint of asthenopia in the age group of 21-40 with a frequency of 28 respondents $(58.4 \%)$ and the respondents with the age group 41-60 years had the highest rank with a frequency of 10 respondents $(20.9 \%)$. This is in line with the research conducted by Riski and friends on employees of computer users at Grapari Telkomsel Kendari in 2014 who found that the highest number of asthenopia in the age group of 21-40 is headache with a frequency of 35 respondents $(50.67 \%)$ and the respondents with the age group 41-60 years had the highest ranking of headaches with a frequency of 30 respondents $(60.9 \%)$ [10].

Based on gender, category that experienced the most asthenopia disorders in men is headache with frequency as many as 21 respondents $(43.8 \%)$, while in women is the blurred vision at close distance with a frequency of 17 respondents $(35.5 \%)$. This is in line with the research conducted by Mansoori and friends who stated that asthenopia complaints in men were headaches with a frequency of 45 respondents $(45 \%)$, whereas in women it was a headache with a frequency of 15 respondents $(35 \%) .6$

Room lighting with the most asthenopia complaints at the setting of $<200$ lux is headache with a frequency of 19 respondents (39.6\%). Most lighting of 200 lux-500 lux rooms are in blurred view at close distance with a frequency of 10 respondents $(23 \%)$ and in room lighting $>500$ lux most are found in tired eyes with a frequency of 11 respondents $(22.9 \%)$. This is in line with the research conducted by Riski and friends on employees of computer users at Grapari Telkomsel Kendari in 2014 stating that in non-ergonomic room lighting the number of complaints of asthenopia is higher compared to ergonomic lighting, for the category of ergonomic room lighting is 200 lux-300 lux. Research conducted on Grapari Telkomsel employees obtained data on room lighting settings $<200$ lux experienced complaints that most with the type of headache complaints by 10 respondents (30\%). Most lighting of 200 lux-500 lux rooms are in blurred view at close distance with a frequency of $5(25 \%)$ respondents, then in room lighting >500 lux most are found in tired eyes with a frequency of 5 respondents $(25 \%)[10]$.

The results showed a high prevalence of asthenopia in headaches, tired eyes, blurred vision, and blurred vision. According to the theory, this is related to the distance from the monitor to the eye, the use of screen filters and room lighting when working with computers that are not ergonomic, repetitive movements and the nature of static work in more than 10 hours a day. 8

\section{Conclusions}

The most experienced complaints are headaches in $38(79.16 \%)$ respondents, tired eyes 36 (75\%) respondents, close blurred views $34(70.8 \%)$ respondents, long-distance blurred vision in $34(70.8 \%)$ respondents, sensitivity to light in $28(58.4 \%)$ respondents, eye redness in 25 
$(52.1 \%)$ respondents, neck strains in $19(39.7 \%)$ respondents, itching in the eyes in $18(37.3 \%)$ respondents, dry eyes or watery eyes in $16(33.3 \%)$ respondents, and double vision as many as $12(25 \%)$ respondents.

\section{References}

[1] Agarwal S, Goel D, Sharma A. Evaluation of the factors which contribute to the ocular complaints in computer users. J Clin Diagn Res.2013; 7(2): 331-335.

[2] Vilela M, Pellanda L, Cesa C, Castagno V. Asthenopia Prevalence and Risk Factors Associated with Professional Computer Use-A Systematic review. International Journal of Advance in Medical Science.2015

[3] Bali J, Neeraj N, Bali RT. Computer vision syndrome: A review. Journal of Clinical Ophthalmology and Research. 2014;2(1): 61.

[4] Ranasinghe P, Wathurapatha WS, Perera YS, Lamabadusuriya DA, Kulatunga S, Jayawardana N, Katulanda P. Computer vision syndrome among computer office workers in a developing country: an evaluation of prevalence and risk factors. BMC research notes. 2016; 9(1): 1.

[5] Suharyanto F X, Safari E. Asthenopia pada pekerja wanita di Call Centre-X. Buletin Penelitian Kesehatan. 2010; 38(3 SEP): 119-130.

[6] Mansoori N, Qamar N, Mubeen SM, Shahid N. Dry Eye Syndrome and Associated Risk Factors among Computer Users in Karachi. Department of Community Health Sciences. Pakistan: Karachi. 2017

[7] Reddy SC, Low CK, LimYP, Low LL, Mardina F, Nursaleha M. P. Computer vision syndrome: a study of knowledge and practices in university students. Nepalese Journal of Ophthalmology. 2013;5(2): 161-168.

[8] Suma'mur DR. Higene Perusahaan dan Kesehatan Kerja. Hiperkes. 2009; p331-363

[9] Mckeown C. Office Ergonomics Practicial Applications. Taylor \& Francis Group. United States of America. 2008; p1-25: p169-181.

[10] Riski IMR, Lestari H, Meiyana PE. Faktor-Faktor yang berhubungan dengan gejala keluhan kelelahan mata pada karyawan pengguna komputer di Grapari Telkomsel Kendari [Skripsi]. Kendari: Program studi Fakultas Kedokteran ,Universitas Haloluleo. 2014 